\title{
PENGARUH KONVERSI BANK KONVENSIONAL MENJADI BANKSYARIAH TERHADAP RISIKO KEBANGKRUTAN STUDI KASUS PADA BANK ACEH
}

\author{
Sinathrya Al Kautsar ${ }^{1}$ \\ Lusiana Indra ${ }^{2}$ \\ Taufan Prasojo Wicaksono $S^{3}$ \\ Dewi Hanggraeni ${ }^{4}$
}

${ }^{1}$ Fakultas Ekonomi Bisnis Universitas Indonesia, Depok, Indonesia e-mail: sinatryaalkautsar.sa@gmail.com / telp: +62 87702534629 ${ }^{2}$ Fakultas Ekonomi Bisnis Universitas Indonesia, Depok, Indonesia ${ }^{3}$ Fakultas Ekonomi Bisnis Universitas Indonesia, Depok, Indonesia ${ }^{4}$ Fakultas Ekonomi Bisnis Universitas Indonesia, Depok, Indonesia

\begin{abstract}
ABSTRAK
Berdasarkan UU No 21 Tahun 2008, prinsip perbankan 2 (dua) jendela di Indonesia akan berakhir pada maksimal di tahun 2023 dimana bank yang selama ini menjalankan bisnis Syariah dengan menggunakan Unit Usaha Syariah (UUS) akan dipaksa untuk melakukan spin off atau konversi menjadi bank umum Syariah. Penelitian ini dilakukan untuk memprediksi kebangkrutan pada bank Aceh setelah dilakukan konversi dari bank Konvensional menjadi bank Syariah. Data penelitian menggunakan data laporan keuangan tahunan periode 2014-2018 dan metode Z-Score dengan proxy rasio keuangan (ROA). Penelitian ini menyimpulkan bahwa H1 dapat diterima dengan hasil Z-Score setelah konversi memperlihatkan perubahan tingkat risiko pada Syariah lebih rendah daripada saat masih menjadi bank Aceh Konvensional.
\end{abstract}

Kata kunci: Z-Score, Aceh, Konversi, Kebangkrutan

\section{ABSTRACT}

Based on Law no. 21 of 2008 concerning Sharia Banking, the 2-window banking principle in Indonesia will expire in year 2023, where banks which have been running sharia businesses using UUS system will be commanded to do a spin-off or convert into Commercial Bank of Sharia. This study was conducted to predict bankcruptcy at Bank Aceh after doing a conversion from Conventional Bank into Islamic Bank in the period of 2014-2018. The data was analyzed by using $Z$-score method with financial ratio ROA. This study concludes that HI can be accepted with risk level after conversion is lowet than when it was still in a Conventional Bank of Aceh.

Keywords: Z-Score, Aceh, conversion, bankruptcy 


\section{PENDAHULUAN}

Berdasarkan Statistik Perbankan Indonesia, pangsa pasar perbankan Syariah hingga bulan Pebruari 2019 sebesar 5.94\% dengan pertumbuhan aset sebesar 13.07\%. Pertumbuhan aset perbankan nasional adalah sebesar $10.34 \%$ dimana Bank Umum Syariah (BUS) berkontribusi sebesar 66.54\% dan Unit Usaha Syariah (UUS) sebesar $33.46 \%$. UUS dapat beroperasi di Indonesia karena sistem perbankan Indonesia masih menganut sistem 2 jendela. Menurut UU No 21 Tahun 2008 tentang perbankan Syariah, prinsip perbankan 2 jendela di Indonesia akan berakhir pada maksimal tahun 2023 dimana bank yang selama ini menjalankan bisnis Syariah dengan menggunakan UUS akan dipaksa untuk melakukan spin off atau konversi.

Kedua pilihan tersebut memiliki kekurangan dan kelebihannya masingmasing, yang mana apabila suatu bank memilih untuk melakukan spin-off maka bank tersebut membutuhkan dana lebih dari Rp 500.000.000.000,- (lima ratus milyar Rupiah) untuk membentuk bank buku 1 yang cenderung sulit untuk dipenuhi, sedangkan untuk melakukan konversi dibutuhkan political will yang kuat dalam mengkonversi bank terlebih lagi pada bank yang dimiliki oleh pemerintah daerah (Peraturan Bank Indonesia No. 11/10/PBI/2009).

Salah satu daerah yang memiliki political will Syariah yang kuat adalah Provinsi Aceh dimana Aceh memiliki otonomi khusus untuk membentuk peraturan daerah Syariah atau biasa disebut Qanun. Qanun Aceh No. 11 Tahun 2018 tentang Lembaga Keuangan Syariah (LKS) Qanun Nomor 8 Tahun 2014 tentang Pokok- 
pokok Syariat Islam mewajibkan bahwa lembaga keuangan yang akan beroperasi di Aceh harus melaksanakan kegiatannya berdasarkan prinsip Syariah. Konsekuensi dari peraturan ini adalah setiap lembaga keuangan di Aceh harus dikonversi menjadi lembaga keuangan Syariah. Konversi ini akan merubah jenis risiko yang dihadapi oleh Bank dan juga akan mempengaruhi risiko kebangkrutan yang dialami oleh bank.

Risiko yang diterima bank Syariah sendiri berbeda dengan bank konvensional yang mana menurut PBI Nomor 13/23 Tahun 2011, bank Syariah memiliki 10 jenis risiko sedangkan bank konvensional hanya memiliki 8 jenis risiko. Risiko khusus pada bank Syariah adalah risiko imbal hasil dan risiko investasi yang mana risiko imbal hasil adalah risiko suatu bank Syariah kehilangan dana pihak ketiga (DPK) karena adanya bagi hasil yang fluktuatif, sedangkan risiko investasi adalah risiko khusus bank Syariah dikarenakan memberikan pendanaan dengan menerapkan bagi hasil. Risiko investasi terjadi bila bank Syariah melakukan akad syirkah dimana bank berperan sebagai sahibul mal dan debitur sebagai mudharib dalam mengelola dana. Akad syirkah terdiri dari 2 jenis yaitu mudharabah dan musyarakah.

Mudarabah atau bagi hasil (Khabir dkk,2015) merupakan hubungan antara bank dan mudarib (peminjam) yang melibatkan hubungan prinsipal-agen, dimana bank Syariah membiayai proyek melalui pengaturan pembagian keuntungan yang disepakati sebelumnya dengan peminjam namun bank tidak berpartisipasi dalam proses pengambilan keputusan dan tidak diizinkan untuk memantau debitur. Lingkungan bank syariah memiliki asimetri informasi yang tinggi sehingga bank Syariah terpapar risiko kredit yang tinggi. Risiko kredit juga dapat timbul jika 
peminjam gagal bayar, baik secara sengaja atau tidak sengaja. Musharakah (atau dikenal juga dengan bagi hasil dan kerugian) mirip dengan kemitraan usaha patungan yang mana bank menyediakan modal dan berbagi laba-rugi dengan rasio yang telah disepakati sebelumnya. Dikarenakan informasi yang tersedia di bank Syariah asimetris, bank Syariah kembali terpapar tingkat risiko kredit yang tinggi dengan mitra investor dengan risiko penurunan nilai modal yang signifikan karena dana yang diinvestasikan oleh bank memiliki peringkat lebih rendah dibandingkan hutang. Bank Syariah juga harus menanggung bagiannya atas kerugian yang ditimbulkan karena kelalaian mitra. Selain karena asimetri informasi jenis akad syrikah, terbatasnya penggunaan praktisi teknik manajemen risiko di bank Syariah bisa menjadi alasan lain risiko kredit bank Syariah menjadi lebih tinggi. Hal ini dikarenakan bank Syariah tidak diizinkan untuk menggunakan instrumen berbasis utang untuk memitigasi risiko kredit, atau metode spekulatif apa pun, termasuk swap, future, dan option dibawah ketetapan Syariah. Oleh karena itu, dalam kasus gagal bayar peminjam, bank Syariah wajib menanggung seluruh kerugian dana peminjam yang membuat bank Syariah lebih berisiko daripada bank konvensional (Errico dan Sundararajan, 2002; Iqbal dan Llewellyn, 2002; Bourkhis dan Nabi, 2013). Ketidakmampuan untuk memberikan denda terhadap peminjam pada saat gagal bayar juga menimbulkan masalah moral hazard di antara peminjam. Peminjam dapat mengambil kesempatan untuk berinvestasi proyek berisiko atau dapat menyalahgunakan dana yang diberikan sehingga meningkatkan risiko kredit untuk diri mereka sendiri dan bank. 
Walau demikian, bank Syariah memiliki beberapa keunggulan dibandingkan dengan bank konvensional dimana bank Syariah menawarkan produk pembiayaan yang lebih beragam dari bank konvensional seperti melakukan akad jual beli (Bai), sewa menyewa (Ijarah) dan Gadai (Rahn). Murabahah merupakan penjualan barang dengan margin yang diberitahukan (Kabir, Worthington dan Gupta,2015). Produk keuangan Syariah yang paling populer adalah Murabahah yang memberikan kontribusi hampir 70\%-80\% dari semua transaksi bank Syariah. Murabahah adalah kontrak berbasis penjualan di mana pembeli (peminjam) memberikan informasi yang diperlukan kepada bank mengenai persyaratan pembeliannya. Bank kemudian membeli produk dan menjualnya kepada pembeli dengan margin keuntungan. Risiko kredit timbul ketika pelanggan gagal untuk menghormati kewajiban pembayaran pada saat pengiriman produk (Karim dan Archer 2013). Sementara Ijarah (leasing) adalah produk keuangan populer lainnya di perbankan Syariah dengan risiko kredit yang lebih rendah dibandingkan produk keuangan Syariah lainnya. Bank akan terkena risiko kredit jika terjadi gagal bayar penyewa saat masa sewa mengalami jatuh tempo.

Berdasarkan prinsip bank Syariah, bank Syariah dapat berbagi kerugian dengan deposan sehingga mengurangi risiko kredit dari bank Syariah tersebut. Nasabah bank Syariah sebagian besar memiliki motivasi agama yang tinggi sehingga cenderung lebih jujur dibandingkan bank konvensional. Risiko di bank Syariah belum dapat disimpulkan lebih rendah atau lebih tinggi dari bank konvensional. Menurut Hossain (2014) yang juga menjelaskan bahwa perilaku ekonomi seorang muslim diikat oleh tiga prinsip umum yang salah satunya adalah 
kepercayaan akan adanya akhirat dan pembalasan. Berdasarkan data empiris perbedaan risiko bank Syariah dan bank konvensional telah banyak penelitian dengan beberapa hasil yang berbeda-beda. Perbedaan risiko yang diterima oleh bank Syariah dan bank Konvensional memberikan bukti empiris yang berlainan antara satu penelitian dengan penelitian lainnya yang mana penelitian oleh Sorwar et all (2016) pada periode penelitian 2000-2013 dengan sampel 65 bank secara acak dari seluruh dunia menunjukkan dengan analisis univariat tidak menemukan perbedaan yang mencolok antara bank Syariah dan konvensional. Namun, korelasi dinamis yang diperoleh melalui pengaturan multivariat menunjukkan bank Syariah menjadi kurang berisiko untuk kedua set bank konvensional khususnya selama krisis keuangan global baru-baru ini. Penelitian yang dilakukan oleh Kabir, Md Nurulet.all.(2015) yang membandingkan risiko kredit pada bank Syariah dan konvensional pada 13 Negara anggota Organisasi Negara Islam dengan penelitian pada 193 bank diantaranya 37 adalah bank Syariah dan 156 bank konvensioanal pada periode penelitian tahun 2000-2012 menunjukkan bahwa apabila bank Syariah diukur oleh informasi akuntansi akan memiliki risiko yang lebih tinggi sedangkan apabila diukur oleh market-based credit risk measure dengan proksi Merton's distance-to-default (DD) model maka credit risk, bank Syariah lebih rendah dibandingkan bank konvensional. Menurut penelitian Hamdi et all (2017), kestabilan bank Syariah dan konvensional pada periode penelitian 2007-2012 selama krisis subprime dan eurozone di 13 negara menunjukkan bahwa bank Syariah lebih stabil dibandingkan dengan bank konvensional. 
Banyaknya hasil penelitian empiris yang mendukung bahwa bank Syariah memiliki tingkat risiko yang lebih rendah dibandingkan bank konvensional maka sudah sesuai dengan Qanun Aceh No. 11 Tahun 2018 tentang Lembaga Keuangan Syariah (LKS) dan Qanun Nomor 8 Tahun 2014 tentang pokok-pokok Syariat Islam yang mewajibkan lembaga keuangan yang akan beroperasi di Aceh harus melaksanakan kegiatannya berdasarkan prinsip Syariah sebelum peraturan tersebut dijalankan di tahun 2020. Penelitian ini mencoba melihat pengaruh konversi bank Aceh menjadi bank Aceh Syariah yang telah dilakukan sejak tahun 2016. Bank Aceh merupakan bank pertama yang melakukan konversi ke bank Syariah. Penelitian ini bertujuan untuk mengetahui risiko kebangkrutan atas kewajiban konversi yang akan diterapkan pada tahun 2020 oleh pemerintah daerah Aceh terhadap bank konvensional di daerah Aceh.

H1: Konversi bank Aceh menjadi bank Aceh Syariah berpengaruh terhadap risiko kebangrutan.

\section{METODE PENELITIAN}

Penelitian ini bertujuan untuk melihat kebijakan di wilayah Aceh yang akan melakukan konversi terhadap perbankan konvensional menjadi Syariah. Saat ini sudah terdapat 1 bank yang melakukan konversi yaitu Bank Aceh. Bank Aceh didirikan secara konvensional pada tahun 1973 dengan nama PT Bank Pembangunan Daerah Aceh (PT BPD Aceh) hingga pada tahun 2016 yang kemudian dikonversi menjadi bank Syariah. Perubahan menjadi bank Syariah 
tentunya disertai dengan perubahan model bisnis pada bank Aceh, sehingga akan merubah risiko dari Bank Aceh yang sebelumnya terdapat 8 jenis risiko berubah menjadi 10 jenis risiko yang pada akhirnya akan berdampak pada perubahan risiko kebangkrutan pada bank konversi. Penelitian ini mencoba membandingkan risiko kebangkrutan Bank Aceh dengan menggunakan data laporan keuangan 2 tahun sebelum dan 2 tahun sesudah konversi dengan menggunakan data laporan keuangan bulanan pada Sepetember 2014 - Agustus 2016 untuk data ketika masih berupa bank konvesional atau sebelum melakukan konversi dan data laporan keuangan bulanan pada September 2016 - September 2018 untuk data sebagai bank Syariah atau setelah dilakukannya konversi.

Pengukuran risiko kebangkrutan pada bank Aceh/ bank Syariah digunakan angka $Z$-Score, dimana Z-Score adalah proxy untuk mengukur stabilitas yang menggambarkan terjadinya kebangkrutan. Z-Score menilai stabilitas ditingkat bank secara keseluruhan dimana Z-Score mengukur peredam yang dimiliki bank baik laba dan modal serta standar deviasi dari laba pada bank. Metode Z-Score mengukur seberapa besar standar deviasi suatu bank dalam menggunakan modal yang dimiliki. Pada penelitian sebelumnya, Faye et al (2013), Rajhi and Hassairi (2014) telah melakukan penelitian credit risk pada bank Syariah dengan metode Z-Score, pada penelitiannya menyepakati bahwa model Z-Score lebih tepat untuk melihat risiko pada perbankan Syariah. Hasil yang berbeda diperoleh dari penelitian di dalam negeri yang dilakukan oleh Endri (2008) yang mendapatkan hasil bahwa model Altman Z-Score dalam memprediksi kebangkrutan bank umum Syariah selama tahun 2005-2007 kurang tepat untuk memprediksi kebangkrutan. 
Pada penelitian ini akan digunakan perhitungan perbandingan risiko kebangkrutan dengan menggunakan metode Z-Score. Penggunaan Z-Score sendiri dipilih karena lebih mudah karena hanya membutuhkan data dari laporan keuangan dan dapat memberikan informasi lebih banyak daripada alat ukur lain seperti NPL/F karena standar yang diberikan mengenai kredit macet berbeda-beda antar bank. Cihak and Hesse (2010) meneliti kekuatan Z-Score dalam memprediksi kegagalan bank menggunakan data bank dari 29 negara di mana 12 negara mengalami kegagalan sistemik. Menurut hasil temuan Cihak and Hesse (2010), bank yang gagal selama krisis memiliki Z-Score yang jauh lebih rendah. Implementasi prediksi kebangkrutan pada perusahaan perbankan di Indonesia telah dilakukan oleh (Sagho dan Merkusiwati, 2015) menggunakan metode yang berbeda yaitu metode Altman Z-Score. Data Z-Score yang kami gunakan adalah 24 bulan sebelum konversi dan 24 bulan setelah konversi. Setelah mendapatkan data Z-Score sebelum dan setelah dilakukan konversi maka akan diadakan uji beda T-test dengan metode paired sample test (Uji Paired Sample $T$ Test) yang merupakan pengujian untuk membandingkan selisih dua mean dari dua sampel yang berpasangan dengan asumsi data berdistribusi normal. Sampel berpasangan berasal dari subjek yang sama, setiap variabel diambil saat situasi dan keadaan yang berbeda. Hogg dan Tanis (1998), pada penelitiannya mengatakan bahwa apabila jumlah sampel data lebih dari 25 atau 30, secara statistik akan lebih memberikan makna, namun dalam kasus yang distribusi datanya simetris, unimodal dan kontinu, jumlah data bahkan sebesar 4 atau 5 masih dapat menghasilkan estimasi hasil penelitian yang memadai 
sehingga dengan data yang digunakan oleh peneliti yaitu 24 bulan sebelum dan 24 bulan setelah konversi diyakini dapat menggambarkan tujuan dari penelitian ini.

Rumus Z-Score adalah

$$
\text { Z-Score }=(R O A+E / A) / S . D R O A
$$

Keterangan: ROA adalah laba bersih dibagi dengan total aset, E / A adalah total ekuitas dibagi dengan total aset, dan SD ROA adalah Standar deviasi ROA selama tiga periode.

\section{HASIL DAN PEMBAHASAN}

\section{Tabel 1.}

Perubahan sebelum dan setelah dilakukan konversi pada Bank Aceh

\begin{tabular}{|c|c|c|}
\hline & Bank Aceh & Bank Aceh Syariah \\
\hline Visi & $\begin{array}{l}\text { Mewujudkan Bank Aceh } \\
\text { menjadi bank yang sehat, } \\
\text { tangguh, handal dan terpercaya } \\
\text { serta dapat memberikan nilai } \\
\text { tambah yang tinggi kepada } \\
\text { mitra dan masyarakat. }\end{array}$ & $\begin{array}{l}\text { Menjadi Bank Syariah terdepan } \\
\text { dan terpercaya dalam pelayanan } \\
\text { di Indonesia }\end{array}$ \\
\hline $\begin{array}{l}\text { Akad dan } \\
\text { aspek legalitas }\end{array}$ & Hukum Positif & Hukum Islam \\
\hline Struktur & Direktur dan Komisaris & Direktur,Komisaris, Dewan \\
\hline Organisasi & & $\begin{array}{l}\text { Pengawas Syariah, Dewan } \\
\text { Syariah Nasional }\end{array}$ \\
\hline Model Bisnis & $\begin{array}{l}\text { Semua usaha sesuai ketentuan } \\
\text { APU/ PPT }\end{array}$ & $\begin{array}{l}\text { Semua usaha sesuai ketentuan } \\
\text { APU/ PPT ditambah yang sesuai } \\
\text { syariat Islam }\end{array}$ \\
\hline Risiko & Kredit, Pasar, Operasional, & 8 risiko ditambah Risiko Imbal \\
\hline Operasional & $\begin{array}{l}\text { Likuiditas, Reputasi, Hukum, } \\
\text { Stratejik, Kepatuhan }\end{array}$ & Hasil dan Investasi \\
\hline Hubungan & Debitur dan Kreditur & Kemitraan dan Kepercayaan \\
\hline
\end{tabular}

Tabel 1 merupakan data perbandingan perubahan dari bank Aceh sebelum dan setelah dilakukan konversi. Perbedaan titik terberat adalah pada cara bank Aceh 
menjalankan usaha dalam Syariah. Perubahan menjadi Syariah juga merubah visi dan prinsip bisnis mengikuti syariat Islam dalam menjalankan operasional perbankan. Bank Aceh juga harus mengikuti ketentuan penerapan risiko operasional dari bank konvensional menjadi bank Syariah dengan tambahan risiko imbal hasil dan investasi. Perubahan menjadi bank Syariah juga menambah jajaran organisasi pengawas yaitu Dewan Pengawas Syariah dan Dewan Syariah Nasional.

Perubahan model bisnis menjadi Syariah umumnya akan membuat perubahan pada kinerja keuangan perusahaan dan tingkat risiko yang diterima, salah satunya pada rasio ROA dan risiko kebangkrutannya. ROA menurut Brigham dan Houston (2013), merupakan rasio laba bersih terhadap total aktiva mengukur pengembalian atas total aktiva (ROA) setelah bunga dan pajak. ROA merupakan rasio yang dapat menggambarkan tingkat profitabilitas.

\section{Grafik1.}

Perhitungan ROA sebelum dilakukan konversi pada Bank Aceh

$\left.\begin{array}{l}0.40 \% \\ 0.35 \% \\ 0.30 \% \\ 0.25 \% \\ 0.20 \% \\ 0.15 \% \\ 0.10 \% \\ 0.05 \% \\ 0.00 \% \\ -0.05 \% \\ -0.10 \% \\ -0.15 \% \\ -0.20 \% \\ -0.25 \% \\ -0.30 \% \\ -0.35 \% \\ -0.40 \% \\ -0.45 \% \\ -0.50 \%\end{array}\right]$


Grafik2.

Perhitungan ROA setelahdilakukan konversi pada Bank Aceh

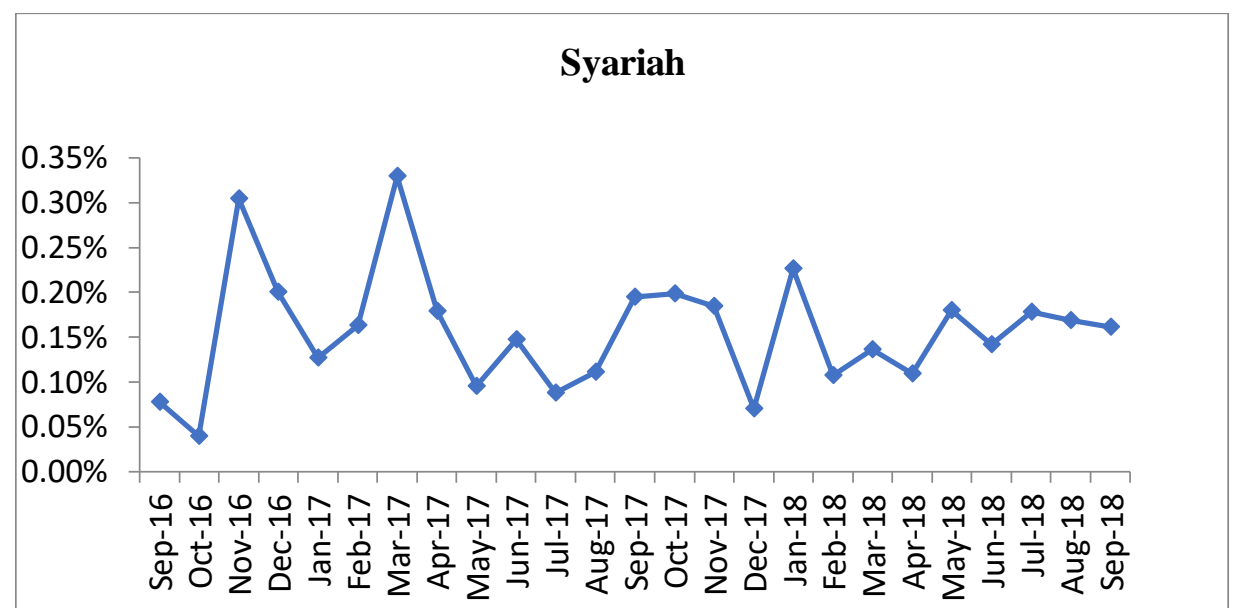

Data Bank Aceh menunjukkan bahwa pada saat masih menjadi bank konvensional terlihat grafik ROA berfluktuatif setiap bulannya dan mengalami ROA negatif pada Desember 2014. Grafik ROA pada model bisnis bank Aceh secara konvensional tertinggi dapat mencapai 0,40\%. Grafik kedua menggambarkan ROA pada bank Aceh setelah menjalani model bisnis secara Syariah, dapat dilihat bahwa grafik lebih tidak berfluktuasi dan mengalami kenaikan disetiap bulannya. Semakin besar ROA, menunjukkan kinerja perusahaan yang semakin baik karena meningkatnya pengembalian atas investasi. Menurut (Wild, Subramanyam, dan Halsey, 2005:65) nilai ROA mencerminkan pengembalian perusahaan dari seluruh aktiva (atau pendanaan) yang diberikan pada perusahaan. Berdasarkan perbandingan ROA bank Aceh konvensional dan setelah dikonversi menjadi bank Aceh Syariah dapat disimpulkan bahwa model bisnis Syariah menunjukkan ROA yang lebih baik. 
Grafik dibawah merupakan perbandingan nilai perhitungan Z-Score bulanan bank Aceh dan bank Aceh Syariah. Perhitungan Z-Score menggambarkan bahwa semakin tinggi nilai Z-Score maka semakin jauh bank dari risiko.

\section{Grafik 3.}

Perhitungan Z-Score pada Bank Aceh Konvensional

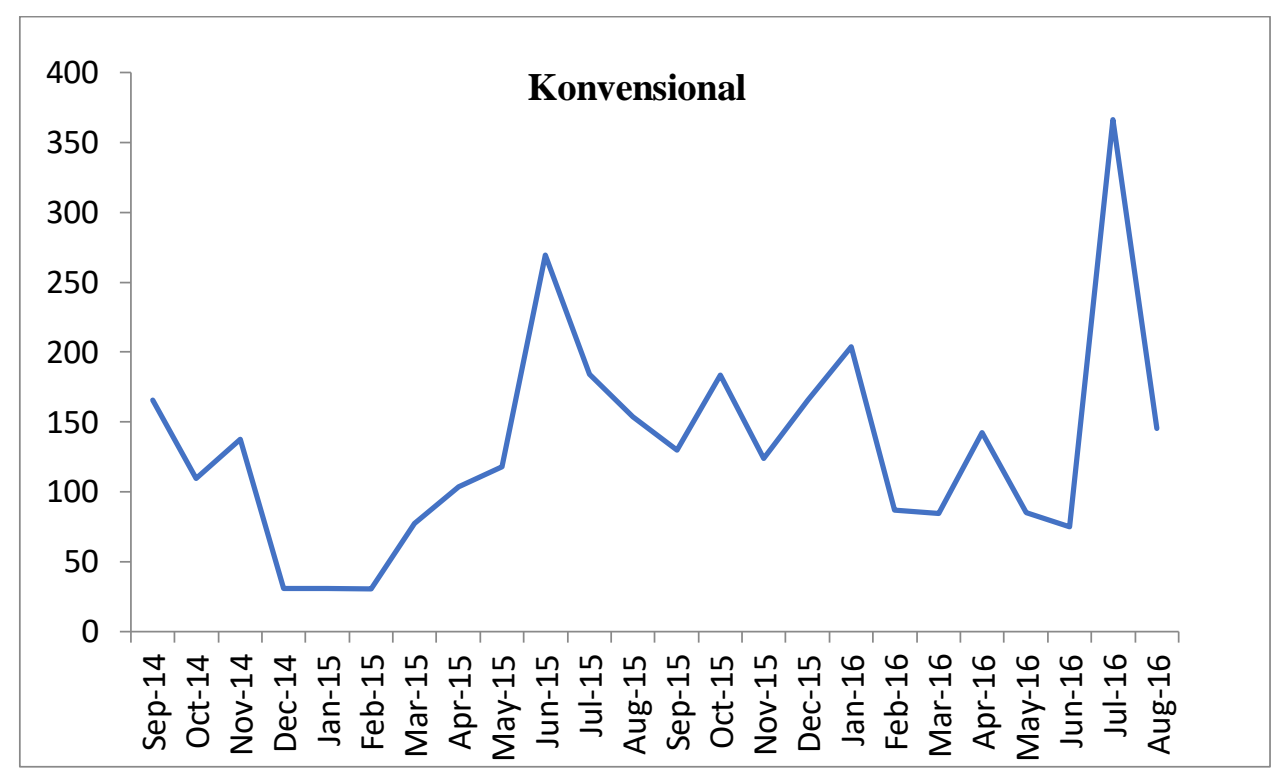

Grafik 4.

Perhitungan Z-Score pada Bank Aceh Konvensional

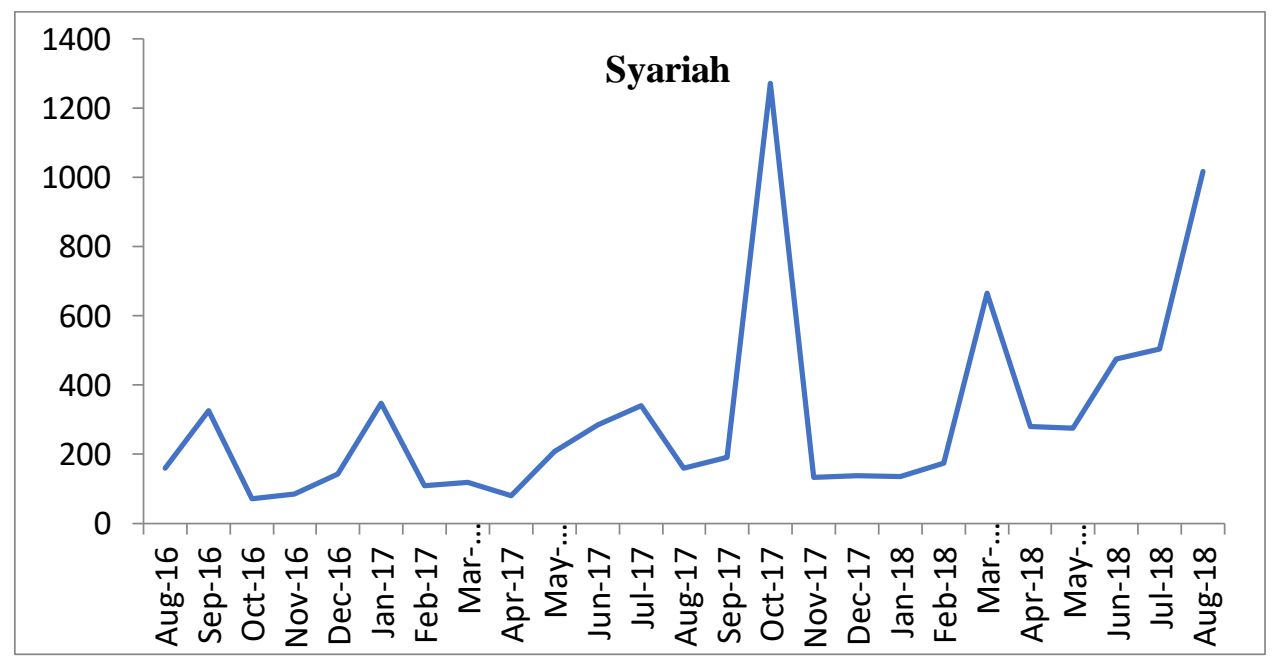


Sumber: laporan keuangan tahunan Bank Aceh 2014-2018

Uji Paired Sample T-Test dilakukan untuk melihat apakah sampel berpasangan mengalami perubahan yang bermakna. Hasil uji Paired Sample T-Test ditentukan oleh nilai signifikansinya. Nilai signifikansi $(2$-tailed $)<0.05$ menunjukkan adanya perbedaan yang signifikan antara variabel awal dengan variabel akhir. Hal ini menunjukkan bahwa terdapat pengaruh yang bermakna terhadap perbedaan perlakuan yang diberikan pada masingmasing variabel. Nilai signifikansi (2-tailed) $>0.05$ menunjukkan tidak terdapat perbedaan yang signifikan antara variabel awal dengan variabel akhir.

Table 2.

Descriptive Statistic

\begin{tabular}{|c|c|c|c|c|c|}
\hline \multicolumn{6}{|c|}{ Paired Samples Statistics } \\
\hline & & Mean & $\mathrm{N}$ & Std. Deviation & Std. Error Mean \\
\hline \multirow{2}{*}{ Pair 1} & Sebelum & 133.5317 & 24 & 75.81201 & 15.47506 \\
\hline & $\begin{array}{l}\text { Setelah } \\
\text { nat }\end{array}$ & 278.4458 & 24 & 258.94648 & 52.85723 \\
\hline
\end{tabular}

Tabel 2 paired samples statistic memperlihatkan output bahwa rata-rata sebelum dan setelah mengalami peningkatan nilai dari 133,5317 menjadi 278,4458 . Dalam teori $Z$ Score, nilai Z-Score yang semakin tinggi menggambarkan risiko kebangkrutan yang lebih baik, sehingga bisa disimpulkan bahwa konversi ke Syariah membuat bank Aceh lebih baik dari segi tingkat risiko kebangkrutannya.

Table 3.

Hasil Uji Paired Sample T-Test

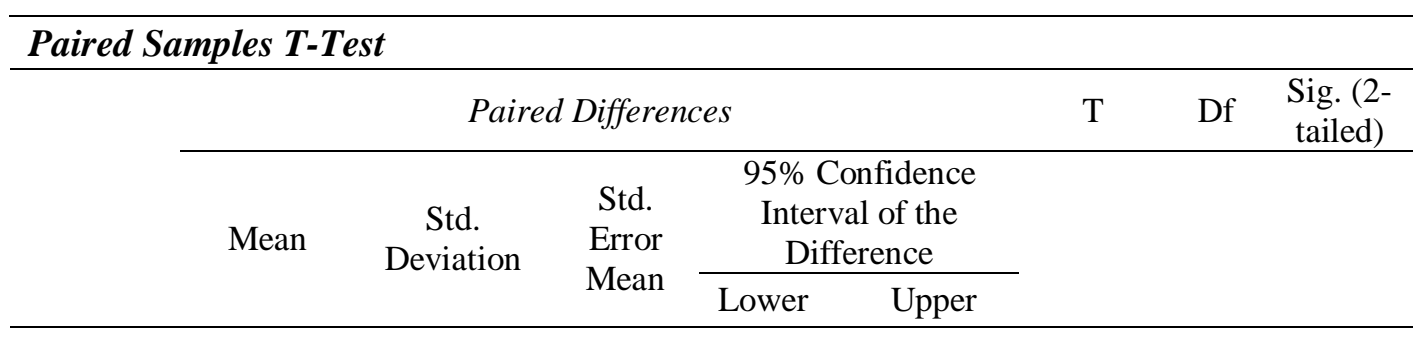




\begin{tabular}{|c|c|c|c|c|c|c|c|c|}
\hline $\begin{array}{l}\text { Sebelum } \\
\text { dan } \\
\text { Setelah }\end{array}$ & -144.914 & 258.922 & 52.852 & -254.247 & -35.581 & -2.742 & 23 & 0.012 \\
\hline
\end{tabular}

Hasil pada Tabel 3 menunjukkan tidak terdapat pengaruh yang bermakna terhadap perbedaan perlakukan yang diberikan oleh masing-masing variabel. Hasil pada table tersebut menunjukkan signifikansi (2-tailed) sebesar 0,012 atau $<0,05$ sehingga dapat disimpulkan bahwa terdapat pengaruh risiko kebangkrutan yang signifikan dari Bank Aceh menjadi Bank Aceh Syariah.

\section{SIMPULAN DAN SARAN}

Penelitian ini menyimpulkan bahwa H1 dapat diterima dikarenakan hasil konversi menjadi bank Syariah memperlihatkan perubahan tingkat risiko pada Syariah lebih baik dari pada saat menjadi bank Aceh konvensional. Penelitian ini mendapatkan hasil bahwa terdapat pengaruh signifkan hasil konversi dari Bank Konvensional menjadi Bank Syariah. Hasil Z-Score yang meningkat disebabkan oleh NPF/L yang menurun ketika bank aceh mengalami konversi yang sudah sesuai dengan penelitian Baele, Farooq dan Ongena (2012) yang mana nasabah bank Syariah lebih religius dibandingkan bank konvensional sehingga risiko gagal bayar mengalami penurunan.

Kebijakan daerah Aceh untuk melakukan konversi perbankan menjadi Syariah dapat diterapkan kepada bank konvensional lainnya karena berdasarkan studi kasus bank Aceh memberikan hasil positif terhadap tingkat risiko kebangkrutan dalam menjalankan model bisnis Syariah. Aceh merupakan salah satu daerah dimana mayoritas masyarakatnya merupakan pemegang kepercayaan Islam sehingga penerapan Syariah pada perbankan dapat berjalan dengan baik. Berdasarkan hasil Z-Score setelah dilakukannya konversi, bank Aceh terlihat lebih baik sehingga dapat dijadikan gambaran untuk bank lainnya bahwa terdapat hal positif dalam konversi Syariah di Aceh terhadap bisnis perbankan. 
Penelitian ini terbatas pada studi kasus bank Aceh dikarenakan saat ini baru bank Aceh yang telah melakukan konversi namun peraturan konversi memiliki batas waktu hingga 2020 di Aceh. Diharapkan pada penelitian selanjutnya dapat menggunakan sampel bank yang lebih banyak sehingga lebih terlihat bagaimana perubahan model bisnis perbankan di Aceh menjadi Syariah benar-benar memberikan tingkat kebangkrutan yang semakin kecil bagi perbankan keseluruhan.

\section{REFERENSI}

Bourkhis, K., Nabi, M.S., 2013. Islamic and conventional banks' soundness during the 2007-2008 financial crisis. Rev. Financ. Econ. 22,68-77.

Brigham, Eugene F. and Joel F. Houston. 2013. Dasar-dasar Manajemen Keuangan (terjemahan). Jakarta. Salemba Empat

Errico, L., Sundararajan, V., 2002. Islamic Financial Institutions and Products In The Global Financial System: Key Issues In Risk Management And Challenges Ahead. International Monetary Fund.

Endri. 2008. Prediksi Kebangkrutan Bank Untuk Menghadapi dan Mengelola Perubahan Lingkungan Bisnis: Analisis Model Altman Z-Score. Perbanas Quarterly Review. Vol.2.

Faye, I., Triki, T., Kangoye, T., 2013. The Islamic finance promises: evidence from Africa. Rev. Dev. Financ. 3, 136-151.

Hogg, Robert V dan Tannis, Elliot A. 1988. Probability and Statistical Inference. Macmillan

Hossain, Basharat., 2014 Economic Rationalism and Consumption: Islamic Perspective. Journal of Economics and Sustainable Development

Ihak, M., Hesse, H., 2010. Islamic banks and financial stability: an empirical analysis. J. Financ. Serv. Res. 38, 95-113.

Iqbal, Llewellyn, D.T., 2002. Islamic Banking and Finance: New Perspectives On Profit Sharing And Risk. Edward Elgar Publishing. 
Kabir, Md Nurul et.all. (2015) Comparative credit risk in Islamic and conventional bank. Pacific-Basin Finance Journal

Karim, Rifaat Ahmed Abdel dan Archer, Shimon. (2013) Islamic Finance: The New Regulatory Challenge, 2nd Edition, Singapura. John Wiley \& Sons (Asia) Pte Ltd Laporan Keuangan Bank Aceh (2014-2018)

Peraturan Bank Indonesia No. 13/1/PBI/2011 Tentang Penilaian Tingkat Kesehatan Bank Umum.

Peraturan Bank Indonesia No. 8/4/PBI/2006. "Tentang Pelaksanaan GCG Bagi Bank Umum". Peraturan Bank Indonesia No.15/12/PBI/2013. "Tentang Kewajiban Penyediaan Modal Minimum".

Qanun Aceh No. 11 Tahun 2018 “Tentang Lembaga Keuangan Syariah (LKS)”

Qanun Nomor 8 Tahun 2014 "Tentang Pokok-pokok Syariat Islam”

Rajhi, W., Hassairi, S.A., 2014. Islamic banks and financial stability: a comparative empirical analysis between MENA and southeast Asian countries. Productivité et capital humain dans les pays du Sud de la Méditerranée: Région et Développement No. 37 p. 149.

Sagho dan Merkusiwati. (2015). Penggunaan Metode AltmanZ-Score Modifikasi Untuk Memprediksi Kebangkrutan Bank Yang Terdaftar di Bursa Efek Indonesia.

Sorwar et all.2016. To debt or not to debt: Are Islamic conventional banks less risky than banks? Journal of Economic Behavior \& Organization

Wild, Subramanyam, dan Halsey. (2005). Analisis Laporan Keuangan. Edisi Kedelapan. Diterjemahkan oleh: Yanivi S. Bachtiar dan S. NurwahyuHarahap. Salemba Empat. Jakarta. 